\title{
METABOLIC EFFECT OF PHENYLBUTAZONE IN GOUTY AND NON-GOUTY ARTHRITIS* ${ }^{*}$
}

BY

\author{
E. R. HUFFMAN, G. M. WILSON, C. J. SMYTH, and R. HILL \\ From the Departments of Medicine and Biochemistry, University of Colorado, \\ and the Veterans Administration Hospital, Denver, Colorado
}

(RECEIVED FOR PUBLICATION SEPTEMBER 6, 1954)

Phenylbutazone ("Butazolidin") is an effective therapeutic agent in acute gouty arthritis (Kuzell and co-workers, 1952, 1954; Kidd, Boyce, and Freyberg, 1952, 1953; Stephens, Yeoman, Holbrook, Hill, and Goodin, 1952; Steinbrocker, Berkowitz, Ehrlich, Elkind, and Carp, 1952; Engleman, Krupp, Forsham, Griffin, Johnson, Green, and Goldfien, 1953). It is a synthetic pyrazol derivative, with the chemical designation 3,5-dioxo-1,2-diphenyl-4-nbutylpyrazolidine. In this clinic, 21 patients with 29 acute episodes of gouty arthritis have been treated with oral doses of 100 or $200 \mathrm{mg}$. phenylbutazone 4-hrly. In every instance all joint discomfort was controlled within 24 to $48 \mathrm{hrs}$ and most of the attacks were aborted in 8 to $12 \mathrm{hrs}$.

Although phenylbutazone has been shown to be an effective therapeutic agent in gouty arthritis, and its effectiveness has been associated with a fall in the serum level of urate, there has been disagreement regarding the explanation for this phenomenon. Kuzell and others $(1952,1954)$ and Kidd and others (1953) have reported that the drug has no effect on the excretion of urate. Johnson and others (1954) studied two patients under therapy for periods of 4 days and noted a fall in the serum urate concentration with a reduction in the urine urate. Mason (1954) reported that phenylbutazone had a uricosuric effect in three out of four cases of gout and in one subject with Paget's disease of the bone. In our experience, phenylbutazone causes an increase in urate excretion. The observations which form the basis for this report are in agreement with those of Yü, Sirota, and Gutman (1953), who demonstrated a definite increase in the renal clearance of urate in gouty subjects during short-term infusion experi-

* These studies were aided by grants from the Rocky Mountain Chapter of the Arthritis and Rheumatism Foundation and the Geigy Pharmaceuticals, Inc., New York, New York. Based in part on a thesis submitted by Dr. G. M. Wilson, Jr., to the Faculty of the Graduate School of the University of Colorado in partial fulfilment for the degree of Master of Science in Medicine.

t Based on material presented in a discussion at the annual meeting of the American Rheumatism Association, June, 1954. See p. 366. ments as well as an increased 24-hr urinary urate excretion after oral administration of phenylbutazone.

It has been noted that in gouty patients the elevated plasma urate level generally falls to normal or almost normal shortly after the administration of phenylbutazone. Kidd and others (1952) determined the change in the plasma urate values in fifteen patients with gout and found the average decrease to be $3.5 \mathrm{mg}$. per cent.; in thirteen nongouty patients who had been receiving phenylbutazone, the average decrease was $1.2 \mathrm{mg}$. per cent. The mechanism of this decrease was not established. Kuzell and others $(1952,1954)$ state that, although the uric acid values in the serum promptly fell after the use of phenylbutazone, there was no consistent increase in the urinary excretion coincident with decrease in serum uric acid. Kidd and others (1952), in a study of nine patients with uncontrolled diets, observed no significant increase in output of urinary urate, they suggested that the decrease in plasma concentration of uric acid may not be due to a uricosuric action of this drug. In preliminary studies reported from this laboratory (Smyth, 1953; Huffman and others, 1953) results were obtained contrary to these observations.

\section{Methods}

It was the purpose of this study to obtain information on the effect of phenylbutazone on the serum urate levels and the 24-hr excretion of urinary urate. The uricosuric effect of different serum levels of this drug administered orally was determined.

Daily serum and urinary uric acid levels were determined according to the method reported by Forsham and others (1948). Aliquots of the 24-hr urine were extracted with ethyl ether before the urate determinations were made. Completeness of collection of 24-hr urine specimens was checked with creatinine determinations. All of the patients were on a constant low purine diet containing $50 \mathrm{~g}$. protein. Serial phenylbutazone blood level 
determinations were done, using the method of Burns and others (1953). The daily dose schedule was either $400,600,800$, or $1,200 \mathrm{mg}$. per $24 \mathrm{hrs}$ in divided dosage. Clearance studies, using simultaneous endogenous creatinine and urate determinations, were done on three gouty and five non-gouty subjects. Collection periods were of 20 minutes duration with bladder wash-outs. Creatinine determinations were made by the method of Bonsnes and Taussky (1945).

\section{Results}

Serum and Urinary Uric Acid Changes. - The effect of 8 days of oral administration of phenylbutazone on the serum urate and 24-hr urinary urate excretion in both gouty and non-gouty arthritics is shown in Table I. It is noteworthy that the serum urate decreased after therapy in all instances. The mean fall in the serum urate of the gouty patients was $3.6 \mathrm{mg}$. per cent. (44 per cent. of the mean control value), while the non-gouty patients had a mean fall in the serum urate of $2.4 \mathrm{mg}$. per cent. (42 per cent. of the mean control value). The average fall in the serum urate for doses of 600,800 , and $1,200 \mathrm{mg}$. per $24 \mathrm{hrs}$ was $2 \cdot 4,3 \cdot 8$, and $3 \cdot 2 \mathrm{mg}$. per cent. respectively. The average serum phenylbutazone levels for doses 600 and $800 \mathrm{mg}$. per $24 \mathrm{hrs}$ were 14.3 and $15.4 \mathrm{mg}$. per cent. respectively. Serum drug levels were obtained only in two of the seven patients receiving the $1,200-\mathrm{mg}$. dosage.

The patients with gout showed a peak 24-hr increase in urinary urate excretion averaging $350 \mathrm{mg}$., $\Rightarrow$ while the non-gouty patients had a peak increase of $\stackrel{9}{?}$ $211 \mathrm{mg}$. The maximum rise in the urine urate in sixteen out of nineteen instances occurred before the serum urate reached its lowest level. One patient (Case 9) is of interest; while his serum uric $\stackrel{\varnothing}{\Omega}$ acid fell slightly during therapy, the urinary excretion is of uric acid showed no rise, in fact it decreased. This patient had marked hypertensive cardiovascular renal changes and while under study developed considerable oedema and other manifestations of fluid retention. Only one $24-\mathrm{hr}$ urine urate in all the other gouty patients failed to exceed the control value.

The mean value of urinary urate excretion was determined in ten instances in seven gouty patients, $\vec{V}$ and in nine instances in seven non-gouty patients 을 (Table I). The gouty subjects showed a significant increase in urate excretion. This data was subjected to analysis by the $t$-test and found to be significant at less than the 2 per cent. level. The mean increase in the 24-hr urine urate excretion during the period of phenylbutazone administration was $204 \mathrm{mg}$. per

TABLE I

EFFECT OF DAILY ADMINISTRATION OF PHENYLBUTAZONE ON SERUM AND URINARY URIC ACID

\begin{tabular}{|c|c|c|c|c|c|c|c|c|}
\hline \multirow[b]{2}{*}{ Diagnosis } & \multirow[b]{2}{*}{ Case No. } & \multicolumn{2}{|c|}{ Phenylbutazone } & \multicolumn{2}{|c|}{ Serum Uric Acid } & \multicolumn{3}{|c|}{ Urinary Uric Acid } \\
\hline & & $\begin{array}{l}\text { Dose per } \\
24 \mathrm{hrs} \\
\text { (mg.) }\end{array}$ & $\underset{\text { Serum Level }}{\text { (mg./ml.) }}$ & $\begin{array}{c}\text { Control } \\
\text { (mg./ml.) }\end{array}$ & $\begin{array}{c}\text { After } \\
\text { Therapy } \\
\text { (mg./ml.) } \dagger\end{array}$ & $\begin{array}{c}\text { Control } \\
\text { (mg./24 hrs) }\end{array}$ & $\begin{array}{c}\text { After } \\
\text { Therapy } \\
\text { (mg. } / 24 \mathrm{hrs}) \dagger\end{array}$ & $\begin{array}{c}\text { Mean } \\
\text { Excretion } \\
\text { (mg. } / 24 \mathrm{hrs})\end{array}$ \\
\hline \multirow{4}{*}{ Gouty } & 1 & 400 & $12 \cdot 0$ & $10 \cdot 4$ & $7 \cdot 2(8) \ddagger$ & 348 & $590(6) \ddagger$ & 482 \\
\hline & 2 & $\begin{array}{l}600 \\
600\end{array}$ & $\begin{array}{l}14 \cdot 5 \\
14 \cdot 0\end{array}$ & $\begin{array}{l}7.0 \\
7.9\end{array}$ & $\begin{array}{l}2 \cdot 8(9) \\
6.6(5)\end{array}$ & $\begin{array}{l}334 \\
197\end{array}$ & $\begin{array}{l}792 \text { (6) } \\
495 \text { (4) }\end{array}$ & $\begin{array}{l}577 \\
448\end{array}$ \\
\hline & $\begin{array}{l}2 \\
4 \\
5 \\
6\end{array}$ & $\begin{array}{l}800 \\
800 \\
800 \\
800\end{array}$ & $\begin{array}{l}15.2 \\
14.8 \\
15.7 \\
14.2\end{array}$ & $\begin{array}{l}7 \cdot 5 \\
7 \cdot 1 \\
7 \cdot 8 \\
9 \cdot 5\end{array}$ & $\begin{array}{l}3 \cdot 1(7) \\
4 \cdot 1(8) \\
3 \cdot 8(6) \\
3 \cdot 8\end{array}$ & $\begin{array}{l}450 \\
432 \\
* \\
354\end{array}$ & $\begin{array}{cl}752 & (6) \\
643 & (2) \\
* & \\
807 & *\end{array}$ & $\begin{array}{l}657 \\
510\end{array}$ \\
\hline & $\begin{array}{l}7 \\
2 \\
1 \\
8 \\
9\end{array}$ & $\begin{array}{l}1,200 \\
1,200 \\
1,200 \\
1,200 \\
1,200\end{array}$ & & $\begin{array}{r}8 \cdot 2 \\
7.3 \\
7.9 \\
7.8 \\
10 \cdot 1\end{array}$ & $\begin{array}{l}4 \cdot 4 \text { (7) } \\
3 \cdot 2 \text { (5) } \\
4 \cdot 5 \text { (7) } \\
2 \cdot 9(9) \\
9 \cdot 5(7)\end{array}$ & $\begin{array}{l}303 \\
507 \\
349 \\
542 \\
425\end{array}$ & $\begin{array}{rr}879 & (5) \\
896 & (2) \\
728 & (2) \\
1,179 & (4) \\
324 & (1)\end{array}$ & $\begin{array}{l}617 \\
877 \\
639 \\
823 \\
292\end{array}$ \\
\hline \multirow{4}{*}{$\begin{array}{l}\text { Non- } \\
\text { Gouty }\end{array}$} & 10 & 400 & $9 \cdot 0$ & $5 \cdot 6$ & $4 \cdot 3(7)$ & 650 & 891 (9) & 672 \\
\hline & $\begin{array}{l}11 \\
12 \\
13 \\
14\end{array}$ & $\begin{array}{l}600 \\
600 \\
600 \\
600\end{array}$ & $\begin{array}{l}14 \cdot 2 \\
16 \cdot 1 \\
11 \cdot 3 \\
15 \cdot 6\end{array}$ & $\begin{array}{l}7 \cdot 6 \\
4 \cdot 7 \\
5 \cdot 3 \\
7 \cdot 1\end{array}$ & $\begin{array}{l}6 \cdot 0(8) \\
2 \cdot 8(8) \\
3 \cdot 2(7) \\
3 \cdot 6(8)\end{array}$ & $\begin{array}{l}780 \\
453 \\
340 \\
760\end{array}$ & $\begin{array}{rr}859 & (7) \\
596 & (5) \\
704 & (4) \\
1,069 & (1)\end{array}$ & $\begin{array}{l}721 \\
528 \\
545 \\
817\end{array}$ \\
\hline & $\begin{array}{l}15 \\
10 \\
\end{array}$ & $\begin{array}{l}800 \\
800 \\
\end{array}$ & $\begin{array}{l}15 \cdot 9 \\
16.9 \\
\end{array}$ & $\begin{array}{l}6 \cdot 2 \\
5 \cdot 4 \\
\end{array}$ & $\begin{array}{l}2 \cdot 8(7) \\
3 \cdot 0(8) \\
\end{array}$ & $\begin{array}{l}571 \\
650 \\
\end{array}$ & $\begin{array}{ll}876 & (5) \\
864 & (4) \\
\end{array}$ & $\begin{array}{l}692 \\
768 \\
\end{array}$ \\
\hline & $\begin{array}{l}12 \\
16\end{array}$ & $\begin{array}{l}1,200 \\
1,200\end{array}$ & $\begin{array}{l}20 \cdot 2 \\
17 \cdot 6\end{array}$ & $\begin{array}{l}4 \cdot 7 \\
2 \cdot 6\end{array}$ & $\begin{array}{l}1.9(6) \\
1.8(9)\end{array}$ & $\begin{array}{l}453 \\
573\end{array}$ & $\begin{array}{l}604 \text { (11) } \\
667 \text { (2) }\end{array}$ & $\begin{array}{l}546 \\
562\end{array}$ \\
\hline
\end{tabular}

* Interval studies not done.

Values represent lowest level of serum urate and highest level of urine urate obtained.

$\ddagger$ Number in parenthesis represents the day of therapy the maximum value was obtained. 
cent., an increase of 53 per cent. over control values. In these studies, nine out of ten patients showed a positive increase. Case 9, who developed fluid retention, had a mean decrease of $133 \mathrm{mg}$. per $24 \mathrm{hrs}$.

The mean change in the 24-hr urinary urate excretion in the non-gouty subjects was less marked and not significant when analysed by the same statistical method. The mean increase for the nine studies in the non-gouty subjects during the period of phenylbutazone administration was $69 \mathrm{mg}$., an increase of 12 per cent. over the mean control value. The positive change over control values expressed in percentage variation was 3 to 60 in seven out of nine instances. Cases 11 and 16, having a mean excretion less than the control, developed objective manifestations of fluid retention. Case 10 had a mean excretion increase of 3 per cent. while receiving $400 \mathrm{mg}$. phenylbutazone daily with a resulting serum phenylbutazone level of $9 \mathrm{mg}$. per cent.

The response of Case 2 (a patient with gout) to a daily dose of $800 \mathrm{mg}$. phenylbutazone is illustrated in Fig. 1. The serum uric acid values were between 7.2 and $8.0 \mathrm{mg}$. per cent. during the three control days. There was a progressive and stepwise fall of the serum urate, beginning after the first day of therapy and reaching the maximum decrease after the sixth day. The urinary excretion of uric acid increased in a corresponding stepwise fashion and reached a maximum on the sixth day of study. It will be noted that in this particular study the phenylbutazone blood level increased gradually during the first 6 days of treatment and then levelled off at approximately $15 \mathrm{mg}$. per cent. The maximum effect upon the serum level corresponds closely to the maximum blood level of the drug. The average total fall in serum urate to $4.6 \mathrm{mg}$. per cent. was reached by the eighth day. The response in this case is typical of the changes observed in both the gouty and non-gouty patients.

Fig. 2 shows a similar study in a non-gouty arthritic (Case 10) receiving $800 \mathrm{mg}$. phenylbutazone daily. Although the magnitude of the changes is not as great as in the patients with gout, the pattern is the same. The serum phenylbutazone level reached a plateau on the fifth day, at which time the serum uric acid level reached the lowest level and remained relatively constant for the duration of therapy. Urinary uric acid excretion reached its peak on the fourth day of therapy.

Urate Clearance. The effect of oral phenylbutazone on the renal clearance of urate was studied in three gouty and five non-gouty subjects (Table II, overleaf).

Simultaneous endogenous creatinine and urate clearances were determined before treatment and repeated after 8 days of therapy. Preliminary studies demonstrated that further significant change in the serum or urinary uric acid seldom occurred after 8 days of oral administration of the drug. The gouty patients had a mean control urate clearance (Cur) of $4.8 \mathrm{ml} . / \mathrm{min}$. which under therapy increased to $13.3 \mathrm{ml} . / \mathrm{min}$. (increase of 177.9 per cent.). The

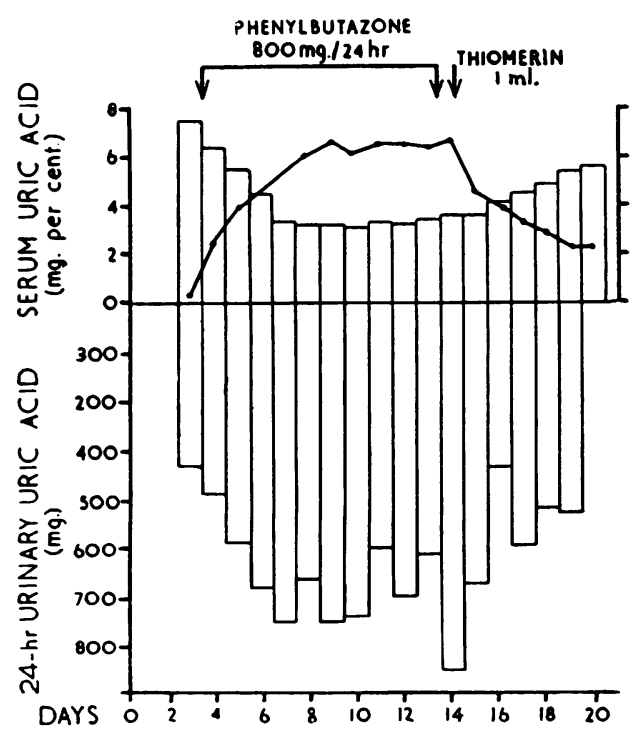

Fig. 1.-Effect of $800 \mathrm{mg}$. oral phenylbutazone daily on serum and urinary uric acid levels in a subject with gout (Case 2).

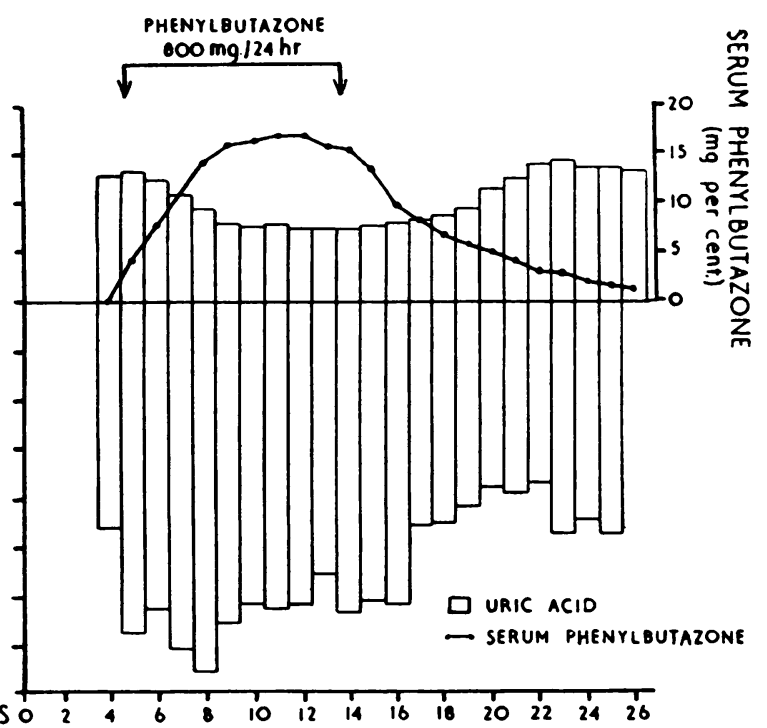

Fig. 2.-Effect of $800 \mathrm{mg}$. oral phenylbutazone daily on serum and urinary uric acid levels in a non-gouty subject (Case 10). 
TADLE II

EFFECT OF EIGHT DAYS' ADMINISTRATION OF PHENYLBUTAZONE ON SERUM URATE AND RENAL CLEARANCE OF URATE

\begin{tabular}{|c|c|c|c|c|c|c|c|c|c|c|c|c|}
\hline \multirow{2}{*}{$\begin{array}{l}\text { Diag- } \\
\text { nosis }\end{array}$} & \multirow{2}{*}{$\begin{array}{l}\text { Case } \\
\text { No. }\end{array}$} & \multirow{2}{*}{$\begin{array}{c}20 \text {-min. } \\
\text { Period }\end{array}$} & \multicolumn{4}{|c|}{ Control } & \multirow{2}{*}{$\begin{array}{c}\text { Phenyl- } \\
\text { buta- } \\
\text { zone } \\
\text { (mg./24 hr) }\end{array}$} & \multirow[b]{2}{*}{$\begin{array}{c}\text { Serum } \\
\text { Phenyl- } \\
\text { buta- } \\
\text { zone } \\
\text { (mg. \%) }\end{array}$} & \multirow[b]{2}{*}{$\begin{array}{c}\text { Serum } \\
\text { Urate } \\
\text { (mg. \%) }\end{array}$} & \multicolumn{2}{|c|}{ After Therapy } & \multirow[b]{2}{*}{$\frac{\text { Cur }}{\mathrm{Ccr}}$} \\
\hline & & & $\begin{array}{c}\text { Serum } \\
\text { Urate } \\
\text { (mg. \%) }\end{array}$ & $\underset{(\mathrm{ml} . / \mathrm{min} .)}{\mathrm{Ccr}}$ & $\underset{(\mathrm{ml} . / \mathrm{min} .)}{\operatorname{Cur}}$ & $\frac{\text { Cur }}{\text { Ccr }}$ & & & & $\underset{(\mathrm{ml} . / \mathrm{min} .)}{\mathrm{Ccr}}$ & $\underset{\text { (ml./min.) }}{\text { Cur }}$ & \\
\hline \multirow{7}{*}{$\begin{array}{l}\text { Non- } \\
\text { Gouty }\end{array}$} & 14 & $\begin{array}{l}1 \\
2 \\
3\end{array}$ & $\begin{array}{l}7 \cdot 0 \\
7 \cdot 2 \\
7 \cdot 2 \\
\end{array}$ & $\begin{array}{l}120 \cdot 0 \\
118 \cdot 9 \\
117 \cdot 9\end{array}$ & $\begin{array}{l}7 \cdot 8 \\
7 \cdot 1 \\
7 \cdot 3\end{array}$ & 0.062 & 600 & $14 \cdot 4$ & $\begin{array}{l}3 \cdot 6 \\
3 \cdot 4 \\
3 \cdot 5\end{array}$ & $\begin{array}{l}123 \cdot 3 \\
120 \cdot 1 \\
118 \cdot 2\end{array}$ & $\begin{array}{l}21 \cdot 8 \\
22 \cdot 5 \\
21 \cdot 7\end{array}$ & 0.183 \\
\hline & 13 & $\begin{array}{l}1 \\
2 \\
3\end{array}$ & $\begin{array}{l}5 \cdot 3 \\
5 \cdot 3 \\
5 \cdot 2\end{array}$ & $\begin{array}{r}105 \cdot 5 \\
98 \cdot 8 \\
97 \cdot 6\end{array}$ & $\begin{array}{l}9 \cdot 2 \\
7 \cdot 8 \\
8 \cdot 0\end{array}$ & 0.083 & 600 & $7 \cdot 5$ & $\begin{array}{l}4 \cdot 7 \\
4 \cdot 8 \\
4 \cdot 8\end{array}$ & $\begin{array}{l}92 \cdot 4 \\
92 \cdot 2 \\
95 \cdot 4\end{array}$ & $\begin{array}{r}10 \cdot 2 \\
9 \cdot 3 \\
10 \cdot 8\end{array}$ & $0 \cdot 108$ \\
\hline & \multirow{3}{*}{10} & $\begin{array}{l}1 \\
2 \\
3 \\
\end{array}$ & $\begin{array}{l}5 \cdot 0 \\
5 \cdot 1 \\
\end{array}$ & $\begin{array}{l}107 \cdot 1 \\
108 \cdot 5\end{array}$ & $\begin{array}{l}8 \cdot 9 \\
8 \cdot 5\end{array}$ & 0.081 & 400 & $7 \cdot 9$ & $\begin{array}{l}4 \cdot 7 \\
4 \cdot 6 \\
4 \cdot 7 \\
\end{array}$ & $\begin{array}{l}91 \cdot 7 \\
96 \cdot 3 \\
93 \cdot 7\end{array}$ & $\begin{array}{l}11 \cdot 3 \\
15 \cdot 7 \\
14 \cdot 5\end{array}$ & $0 \cdot 147$ \\
\hline & & $\begin{array}{l}1 \\
2 \\
3\end{array}$ & & & ; & & 600 & $10 \cdot 2$ & $\begin{array}{l}4 \cdot 7 \\
4 \cdot 3 \\
4 \cdot 5\end{array}$ & $\begin{array}{l}111 \cdot 4 \\
113 \cdot 2 \\
107 \cdot 6\end{array}$ & $\begin{array}{l}11 \cdot 4 \\
13 \cdot 6 \\
11 \cdot 8\end{array}$ & $0 \cdot 111$ \\
\hline & & $\begin{array}{l}1 \\
2 \\
3\end{array}$ & & 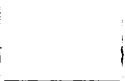 & ! & & 800 & $12 \cdot 8$ & $\begin{array}{l}4 \cdot 1 \\
4 \cdot 1 \\
4 \cdot 1\end{array}$ & $\begin{array}{r}105 \cdot 8 \\
111 \cdot 6 \\
92 \cdot 1\end{array}$ & $\begin{array}{l}20 \cdot 6 \\
18 \cdot 9 \\
18 \cdot 1\end{array}$ & $0 \cdot 186$ \\
\hline & 12 & $\begin{array}{l}1 \\
2 \\
3\end{array}$ & $\begin{array}{l}7 \cdot 0 \\
6 \cdot 8 \\
6 \cdot 8\end{array}$ & $\begin{array}{l}90 \cdot 8 \\
90 \cdot 0 \\
91 \cdot 0\end{array}$ & $\begin{array}{l}4 \cdot 7 \\
4 \cdot 9 \\
4 \cdot 6\end{array}$ & 0.052 & 800 & $15 \cdot 5$ & $\begin{array}{l}4 \cdot 7 \\
4 \cdot 6 \\
4 \cdot 6\end{array}$ & $\begin{array}{r}94 \cdot 6 \\
100 \cdot 2 \\
95 \cdot 3\end{array}$ & $\begin{array}{l}13 \cdot 7 \\
14 \cdot 5 \\
15 \cdot 8\end{array}$ & $0 \cdot 152$ \\
\hline & 15 & $\begin{array}{l}1 \\
2 \\
3\end{array}$ & $\begin{array}{l}6 \cdot 4 \\
6 \cdot 0 \\
6 \cdot 5\end{array}$ & $\begin{array}{r}89 \cdot 5 \\
100 \cdot 0 \\
100 \cdot 7\end{array}$ & $\begin{array}{l}6 \cdot 9 \\
8 \cdot 0 \\
7 \cdot 9\end{array}$ & 0.079 & 800 & $10 \cdot 8$ & $\begin{array}{l}4 \cdot 5 \\
3 \cdot 9 \\
3 \cdot 9\end{array}$ & $\begin{array}{l}85 \cdot 2 \\
87 \cdot 9 \\
82 \cdot 3\end{array}$ & $\begin{array}{l}13 \cdot 8 \\
17 \cdot 8 \\
18 \cdot 6\end{array}$ & $0 \cdot 196$ \\
\hline \multirow{4}{*}{ Gouty } & \multirow{2}{*}{1} & $\begin{array}{l}1 \\
2 \\
3\end{array}$ & $\begin{array}{l}10 \cdot 3 \\
10 \cdot 3 \\
10 \cdot 5\end{array}$ & $\begin{array}{l}77 \cdot 2 \\
70 \cdot 7 \\
84 \cdot 4\end{array}$ & $\begin{array}{l}2 \cdot 7 \\
2 \cdot 3 \\
2 \cdot 7\end{array}$ & 0.033 & 400 & $12 \cdot 0$ & $\begin{array}{l}7 \cdot 2 \\
7 \cdot 1 \\
7 \cdot 2 \\
\end{array}$ & $\begin{array}{l}63 \\
58 \\
56 \\
\end{array}$ & $\begin{array}{l}6 \cdot 8 \\
7 \cdot 2 \\
6 \cdot 1\end{array}$ & $0 \cdot 114$ \\
\hline & & $\begin{array}{l}1 \\
2 \\
3\end{array}$ & & ' & i & & 600 & $16 \cdot 0$ & $\begin{array}{l}6 \cdot 0 \\
6 \cdot 0 \\
6 \cdot 0\end{array}$ & $\begin{array}{l}64 \cdot 9 \\
62 \cdot 7 \\
55 \cdot 0 \\
\end{array}$ & $\begin{array}{l}12.4 \\
12.9 \\
10 \cdot 8\end{array}$ & $0 \cdot 197$ \\
\hline & 17 & $\begin{array}{l}1 \\
2 \\
3\end{array}$ & $\begin{array}{l}7 \cdot 8 \\
8 \cdot 0 \\
8 \cdot 3\end{array}$ & $\begin{array}{l}99 \cdot 2 \\
95 \cdot 1 \\
96 \cdot 1\end{array}$ & $\begin{array}{l}8 \cdot 6 \\
7 \cdot 9 \\
7 \cdot 5\end{array}$ & 0.082 & 400 & $8 \cdot 9$ & $\begin{array}{l}5 \cdot 0 \\
5 \cdot 0 \\
5 \cdot 0\end{array}$ & $\begin{array}{l}111 \cdot 1 \\
112 \cdot 1 \\
118 \cdot 7\end{array}$ & $\begin{array}{l}12 \cdot 6 \\
12 \cdot 7 \\
12 \cdot 3\end{array}$ & $0 \cdot 109$ \\
\hline & 2 & $\begin{array}{l}1 \\
2 \\
3\end{array}$ & $\begin{array}{l}7 \cdot 1 \\
7 \cdot 0 \\
7 \cdot 0\end{array}$ & $\begin{array}{l}83 \cdot 8 \\
82 \cdot 0 \\
77 \cdot 4\end{array}$ & $\begin{array}{l}3 \cdot 8 \\
4 \cdot 2 \\
4 \cdot 0\end{array}$ & 0.049 & 600 & $14 \cdot 5$ & $\begin{array}{l}2 \cdot 8 \\
2.9 \\
2 \cdot 8\end{array}$ & $\begin{array}{l}80 \cdot 7 \\
87 \cdot 4 \\
75 \cdot 4\end{array}$ & $\begin{array}{l}24 \cdot 7 \\
22 \cdot 6 \\
19 \cdot 0\end{array}$ & 0.272 \\
\hline
\end{tabular}

non-gouty patients had a mean control urate clearance of $7.2 \mathrm{ml} . / \mathrm{min}$. which increased under therapy to $15.5 \mathrm{ml} . / \mathrm{min}$. (an increase of 115.2 per cent.).

The creatinine clearance under therapy decreased in both groups; falling from 85.1 to $76.7 \mathrm{ml} . / \mathrm{min}$. in the gouty subjects and from 102.5 to $100 \cdot 5 \mathrm{ml} . / \mathrm{min}$. in the non-gouty. All subjects, both gouty and nongouty, had an increase in the Clearance Urate : Clearance Creatinine ratio ( $\mathrm{Cur}: \mathrm{Ccr})$. In gouty subjects the mean $C u r: C c r$ rose from 0.049 to 0.173 (increase of 257.1 per cent.). In the nongouty subjects the ratio rose from 0.071 to 0.156 (increase of 115.0 per cent.). In the gouty subjects, the mean percentile change ranged from 33 to $497 \cdot 7$; in the non-gouty from $30 \cdot 1$ to $198 \cdot 0$.

The subjects with the lower serum phenylbutazone levels demonstrated less change in the $\mathrm{Cur}: \mathrm{Ccr}$ ratios. For example, the increase in $\mathrm{Cur}: \mathrm{Ccr}$ for the three subjects with phenylbutazone levels below
$10 \mathrm{mg}$. per cent. was $48 \cdot 21$ per cent. above the mean control; patients with levels above $10 \mathrm{mg}$. per cent. showed an increase of $346 \cdot 24$ per cent. The mean $\frac{\bar{\alpha}}{2}$ change in the serum urate with drug levels above $\dot{0}$ $10 \mathrm{mg}$. per cent. was 38.5 per cent., and below $10 \mathrm{mg}$. per cent. the change was $20 \cdot 9$ per cent.

Phenylbutazone Serum Determinations.-Serum 의 phenylbutazone levels were obtained after 8 days of $\supset$ oral therapy in 73 instances. Previous studies (Figs 1 and 2) in this laboratory and elsewhere (Brock, 1953) have shown that by the eighth day on any given dosage, the serum phenylbutazone has $N$ reached a constant level which is unaltered by further ${ }_{\mathrm{W}}$ administration of the same dosage of the drug. 0 It is apparent from Fig. 3 that increasing dosages up to $600 \mathrm{mg}$. $/ 24 \mathrm{hrs}$ result in a steep rise in the corresponding serum levels. Increasing daily dosages $\stackrel{\oplus}{\rightarrow}$ above $600 \mathrm{mg}$. produced a less marked rise in the 0 


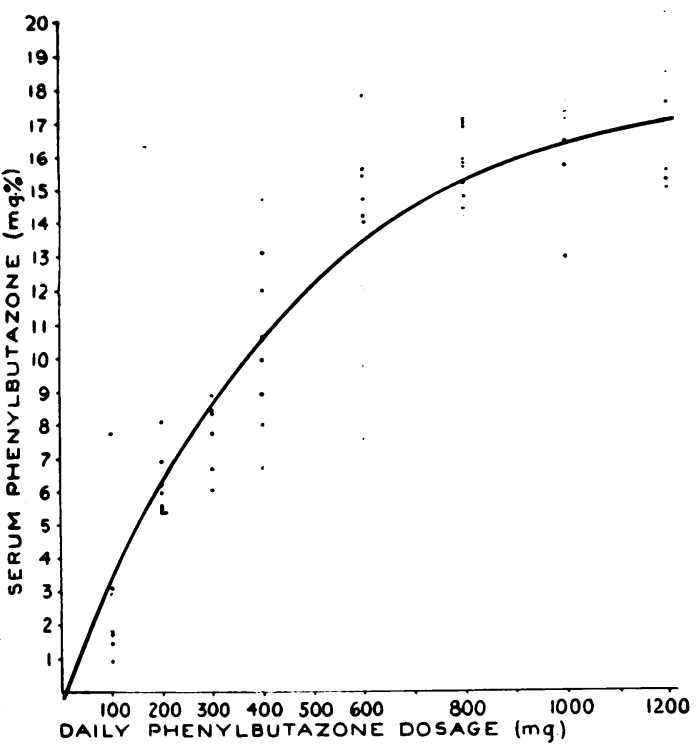

Fig. 3.-Serum phenylbutazone levels after 8 days' oral administration of phenylbutazone.

serum phenylbutazone level. For example, it will be noted that the difference in the average serum phenylbutazone level of patients receiving $200 \mathrm{mg}$. and $600 \mathrm{mg}$. orally per day was $7 \cdot 2 \mathrm{mg}$. per cent., while the difference in average serum levels of patients receiving 600 and $1,000 \mathrm{mg}$. per day of the drug was only $2.5 \mathrm{mg}$. per cent.

All but three of thirteen patients receiving $600 \mathrm{mg}$. and all the patients receiving $800 \mathrm{mg}$. or above daily had serum levels above $10 \mathrm{mg}$. per cent. Figs 1 and 2 demonstrate the rate of increase of serum phenylbutazone when a patient is started on a daily oral intake of $800 \mathrm{mg}$. The pattern of response is similar for all dosages, but the rate of increase varies for different dosages. All of five patients receiving dosages of $800 \mathrm{mg}$. daily or above had serum levels in excess of $10 \mathrm{mg}$. per cent. by the third day. On the contrary, in four patients receiving $600 \mathrm{mg}$. daily, a $10 \mathrm{mg}$. per cent. level was not reached until the 6 th day. The serum response to any given daily oral intake of phenylbutazone varied considerably. The range of variation for all doses averaged $6 \mathrm{mg}$. per cent. After cessation of therapy there was a gradual decline in the serum level over a 7- to 14-day period.

\section{Discussion}

The observations reported in this paper would add phenylbutazone to the list of substances which alter the urate tubular transport mechanism. The increased excretion of urate is contrary to the reports of others (Kuzell and others, 1952, 1954; Kidd, Boyce, and Freyberg, 1953; Johnson and others, 1954; Mason, 1954) and in accord with the work of Yü, Sirota, and Gutman (1953). The studies herein presented have demonstrated in both gouty and non-gouty arthritics a consistent fall in the serum uric acid, an increased clearance of uric acid, and in the gouty subjects a significant increase in 24-hr urate excretion. The mean 24-hr urinary urate excretion for the non-gouty subjects, while not statistically significant, did rise in seven out of nine instances. In both groups, all subjects except Case 9 had single 24-hr urinary excretions of urate which exceeded the control value, and preceded (in sixteen out of nineteen instances) the maximum fall in the serum urate.

It is evident from this data that the alteration in renal function is one of the major mechanisms responsible for the decrease in the serum urate in gouty subjects. The fact that in one gouty and two non-gouty subjects the serum urate level fell while the mean 24-hr urate excretion did not rise, indicates that other mechanisms are at work in decreasing the serum urate level during phenylbutazone therapy. Indeed, Delfel and Griffin (1953), studying the effect of phenylbutazone on rat liver homogenate, reported that the drug apparently decreased the catabolism of nucleic acid. Further, it has been shown that phenylbutazone increases the blood volume (Wilkinson and Brown, 1953; Brodie and others, 1954), thus causing a decrease due to dilution of the serum urate. It is to be noted that all three of the subjects in whom the serum urate fell without a corresponding increase in the urinary urate developed oedema and other manifestations of fluid retention. Fluid retention would appear to explain some of reported observations of the effect of phenylbutazone on serum urate. Johnson and others (1954) studied two patients who were given $1,000 \mathrm{mg}$. of the drug daily, and manifested considerable suppression of all the urinary constituents studied: 24-hr volume, creatinine, urate, sodium, and 17-hydroxy-corticoids. The diversity of substances affected suggests that a general mechanism, such as fluid retention, is responsible for the serum urate change. Mason (1954) noted that, where water retention did not supervene, a marked uricosuric action was effected by the drug. He concluded that phenylbutazone had a slight uricosuric effect and also a salt-and-water retaining effect. Kuzell and others $(1952,1954)$ put forth no urate excretion data to substantiate their claim that the serum urate falls without a corresponding increase in the urine urate. Kidd, Boyce, and Freyberg (1952, 
1953) present little data to support their conclusion that urate excretion is not affected by phenylbutazone. The determinations of urate excretion were not consecutive, and would seem insufficient for this type of study.

Phenylbutazone caused an increased clearance of serum urate in both gouty and non-gouty subjects. The data presented here supports the conclusion of Yü, Sirota, and Gutman (1953) that serum phenylbutazone levels above $10 \mathrm{mg}$. per cent. are necessary to produce a significant increase in the clearance of urate. They noted in short-term infusion experiments that serum phenylbutazone levels below $10 \mathrm{mg}$. per cent. did not significantly increase urate clearance. The subjects in this study with serum phenylbutazone levels below $10 \mathrm{mg}$. per cent. had an increase in the Cur : Ccr ratio of 48 per cent., compared with 345 per cent. in those with drug levels above $10 \mathrm{mg}$. per cent.

While serum levels of phenylbutazone above $10 \mathrm{mg}$. per cent. are necessary to obtain a marked increase in the clearance of urate, it would appear that this drug may be useful as a uricosuric agent. A daily intake of $600 \mathrm{mg}$. or more is necessary to bring about a serum phenylbutazone level of $10 \mathrm{mg}$. per cent. or above. Since in our experience the incidence of toxicity of patients receiving oral phenylbutazone on dosages above $600 \mathrm{mg}$. per cent. is greatly increased, this limits the clinical use of this drug as a long-term uricosuric agent.

The majority of acute attacks of gout can be aborted within 8 to $12 \mathrm{hrs}$ on dosages of either 100 or $200 \mathrm{mg}$. every $4 \mathrm{hrs}$. It is apparent that this particular therapeutic effect is not dependent upon any change in renal function, since the serum phenylbutazone response to orally administered doses of this magnitude seldom results in a serum level high enough to cause a uricosuric effect.

\section{Summary}

(1) Phenylbutazone is an effective therapeutic agent in acute attacks of gout.

(2) Orally administered phenylbutazone is a uricosuric agent.

(3) The fall in the serum uric acid induced by phenylbutazone in the gouty subject corresponds to the increased urinary uric acid excretion.

(4) Three patients in this study demonstrated a fall in serum urate with a decreased mean 24-hr urate excretion. These patients manifested marked fluid retention, and this appears to be a factor in the lowering of serum urate concentration.

(5) The uricosuric effect can be clearly demonstrated at serum phenylbutazone levels above $10 \mathrm{mg}$. per cent.
(6) Dosages above $600 \mathrm{mg} . / 24 \mathrm{hrs}$ are necessary $\frac{\mathrm{C}}{3}$ to obtain a consistent uricosuric effect.

(7) Acute attacks of gout are aborted at serum levels insufficient to cause a uricosuric effect. $\overrightarrow{\vec{F}}$

(8) On a regular daily oral dose, serum phenyl- $\stackrel{?}{+}$ butazone levels reach a plateau between the sixth and eighth day of therapy and remain relatively $\frac{\bar{\sigma}}{\bar{n}}$ constant thereafter.

The phenylbutazone used in these studies was supplied by the Geigy Pharmaceuticals Inc., of New York, $\rightarrow$ through the courtesy of Dr. Albert Hemming to whom we. express our appreciation. The authors gratefully acknowledge the co-operation given this project by the $\omega_{\sigma}^{\omega}$ nursing and dietetic departments of the Veterans Administration Hospital, Denver, Colorado.

\section{REFERENCES}

Bonsnes, R. W., and Taussky, H. H. (1945). J. biol. Chem., 158, 581. Brock, E. (1953). Annual Report, West London Hospital, Department of Rheumatic Diseases. Annals of the Rheumatic Diseases, 13, 252.

Brodie, B. B., Lowman, E. W., Burns, J. J., Lee, P. R., Chenkin, T., $\supset$ Goldman, A., Weiner, M., and Steele, J. M. (1954). Amer. J. Med., 16, 181 .

Burns, J. J., Rose, R. K., Chenkin, T., Goldman, A., Schulert, A., and Brodie, B. B. (1953). J. Pharmacol., 109, 346.

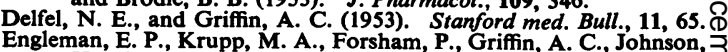
H., Green, T., and Goldfien, A. (1953). Amer. J. Med., 15, 414.

Forsham, P. H., Thorn, G. W., Prunty, F. T. G., and Hills, A. G.

Huffman, E. R., Smyth, C. J., Wilson, G. M., Hill, R. (1953). PR्: $\overrightarrow{0}$ cent. Soc. clin. Res., 26, 49. (Abstr. J. Lab. clin. Med., 42, 8 8 .)

Johnson, H. P.. Engleman, E. P., Forsham, P. H., Krupp, M. . Green, T. W., and Goldfien, A. (1954). New Engl. J. Mra., 250,665 .

Kidd, E. G., Boyce, K. C., and Freyberg, R. H. (1952). Annals $\stackrel{\text { of }}{2}$ the Rheumatic Diseases, 11, 297.

Kuzell, w, C., Schaffarzick, R., W., Brown, B., and Mankle, E. A. ํ. (1952)., J. Amer. med. Ass., 149, 729 . ., and Mankle, E. A. Brown, B. (1954). Amer. J. Med., 16., 212.

Mason, R. M. (1954). Brit. med. J., 1, 788.

Smyth, C. J. (1953). J. Amer. med. Ass., $152,1106$.

Steinbrocker, O., Berkowitz, S., Ehrlich, M., Elkind, M., and Carp, S. (1952). Ibid., 150, 1087.

Stephens, C. A. L., Jr., Yeoman, E. E., Holbrook, W. P., Hill, D. F., and Goodin, W. L. (1952). Ibid., 150, 1084 .

Wilkinson, E. L., and Brown, H. (1953). Amer.J. med. Sci., 225, 153. Yü, T. F,, Sirota, J. H., and Gutman, A. B. (1953). J. clin. Invest.,

Effet métabolique de la phénylbutazone dans l'arthrite goutteuse et non-goutteuse

\section{RÉSUMÉ}

(1) La phénylbutazone est un agent thérapeutiqueo efficace contre l'attaque aiguë de goutte.

(2) Administrée par voie buccale, la phénylbutazone est un agent uricosurique.

(3) La chute de l'acide urique dans le sérum, produite par la phénylbutazone chez les goutteux, correspond à son excrétion urinaire augmentée.

(4) Trois malades dans cette série manifestèrent uneㅇำ chute sanguine des urates accompagnée de leur baisse $\omega$ excrétoire moyenne par 24 heures. Chez tous les maladeso on observa une retention aqueuse marquée, ce qui semble jouer un rôle dans la baisse de la concentration sanguine des urates.

(5) L'effet uricosurique est nettement demontrable aux $\stackrel{\text { ? }}{+}$ taux sériques de la phénylbutazone au-dessus de $10 \mathrm{mg}$. $T$ pour cent. 
(6) Des doses supérieures à $600 \mathrm{mg}$. par 24 heures sont nécessaires pour obtenir un effet uricosurique décisif.

(7) Des attaques aigus de goutte sont avortés à des taux sériques trop bas pour causer un effet uricosurique.

(8) La phénylbutazone, prise régulièrement par voie buccale, atteint entre le sixième et le huitième jour un taux sérique qui demeure à peu près constant.

\section{Efecto metabólico de la fenilbutazona en la artritis gotosa y otra \\ Sumario}

(1) La fenilbutazona es un agente terapéutico eficaz en el ataque agudo de gota.

(2) Por vía oral, la fenilbutazona es un agente uricosúrico.

(3) La baja del ácido úrico en el suero, producida por la fenilbutazona en los gotosos, corresponde a su excreción urinaria aumentada.

(4) En tres enfermos de este grupo hubo una baja sanguínea de uratos acompañada de la reducción de la excreción media por 24 horas. Todos los enfermos acusaron una retención hídrica marcada, lo que parece jugar un papel en la baja de la concentración sérica de uratos.

(5) El efecto uricosúrico es claramente demostrable con concentraciones sanguíneas de fenilbutazona de más de $10 \mathrm{mg}$. por ciento.

(6) Para obtener un efecto uricosúrico decisivo se necesitan doses superiores a $600 \mathrm{mg}$. por 24 horas.

(7) Ataques agudos de gota se ven abortados con concentraciones sanguíneas insuficientes para causar un efecto uricosúrico.

(8) Con tomas diarias por vfa oral, la fenilbutazona alcanza entre el sexto y el octavo día un nivel sanguíneo determinado que se mantiene relativamente fijo. 